Archived version from NCDOCKS Institutional Repository http://libres.uncg.edu/ir/asu/

Holcomb, Jefferson E., Kovandzic, T. V., \& Williams, Marian R. (2011). Civil asset forfeiture, equitable sharing, and policing for profit in the United States. Journal of Criminal Justice, 39, 273-285. Version of record available from Elsevier. [ISSN 0047-2352],

[doi:10.1016/j.jcrimjus.2011.02.010]

\title{
Civil asset forfeiture, equitable sharing, and policing for profit in the United States
}

\author{
By: Jefferson E. Holcomb, Tomislav V. Kovandzic, Marian R. Williams
}

\begin{abstract}
Purpose: Critics of asset forfeiture claim that forfeiture laws create financial incentives that inappropriately influence police behavior. The present study examines the relationship between measures of the financial incentive and legal burdens for civil asset forfeiture on federal equitable sharing payments to local law enforcement to determine whether police behavior is affected by different statutory incentives for forfeiture activity.

Methods: Using LEMAS and DOJ forfeiture data, this study addresses some of the limitations of previous research by using a multi-year average for forfeiture activity, an improved measure of financial incentives for law enforcement, and multiple measures of statutory burdens to law enforcement to determine the impact of forfeiture laws on forfeiture activity.
\end{abstract}

Results: Consistent with anecdotal reports and limited prior research, findings indicate that agencies in jurisdictions with more restrictive state forfeiture laws receive more proceeds through federal equitable sharing.

Conclusions: Results suggest that state and local law enforcement agencies use federal equitable sharing to circumvent their own state forfeiture laws when state laws are more burdensome or less financially rewarding to these agencies, providing additional evidence that police operations are influenced by financial incentives. 


\section{Introduction}

All states and the federal government allow law enforcement to seize and forfeit cash, property, and other materials that they believe are associated with illegal activity (see Edgeworth, 2008). While there are variations among state and federal laws, the essence of such practices is quite similar: police or other investigative agencies seize cash or property (hereafter referred to as "assets") suspected of being associated with criminal activity and then initiate forfeiture actions to permanently deprive an individual of those assets. Forfeiture allows the government to keep the seized cash and property (both personal and real), destroy the property, or sell the property and keep the proceeds to fund a number of activities. Depending on the law, these proceeds can be used for law enforcement purposes, such as to fund investigative activities or purchase equipment. The assets can also be used to pay restitution to crime victims, fund drug education programs, pay prosecutorial expenses, supplement school budgets, or be applied to the general fund of the city, county, or state (Edgeworth, 2008 and Williams, 2002b). Many states and the federal government, however, allow the proceeds from forfeitures to go to law enforcement agencies, resulting in allegations of "policing for profit" (e.g. Blumenson \& Nilsen, 1998;Worrall, 2004 and Worrall and Kovandzic, 2008).

The question of whether law enforcement forfeiture activities are influenced by a "profit motive" has been subject to only a limited number of empirical studies (see Benson et al., 1995 and Worrall and Kovandzic, 2008). Following the lead of Worrall and Kovandzic (2008), we examine whether local law enforcement agencies' decision to participate in the Federal government's equitable sharing program are influenced by the share of proceeds the agency could have received under their own state law. However, rather than measuring forfeiture proceeds dichotomously (either all proceeds to returned to law enforcement or less than 100 percent), we use a more refined measure capturing the minimum percentage of proceeds that may be returned to law enforcement agencies under state law. In addition, we extend their earlier work by considering how procedural barriers, such as the standard of proof required for the state to prevail in forfeiture proceedings and which party has the burden to establish or defeat "innocent owner" claims, operate independently and in combination with each other to affect decisions on whether to pursue forfeiture actions through the federal equitable sharing program.

The first section of the paper provides a brief overview of contemporary civil forfeiture laws. Next, we examine federal equitable sharing and the various reasons for its use by state and local law enforcement. The following section discusses how financial rewards and limited procedural safeguards provide powerful incentives to engage in "policing for profit" and reviews the limited research on this question. Following a description of the data and methods for the current study, results of the analyses is presented. In the final section, we consider the policy implications of our findings.

\section{Types of asset forfeiture}

Nearly all forfeiture actions begin when, in the course of their duties, law enforcement agents determine that there is probable cause to believe that illegal activity has occurred. Under such circumstances, the agents can seize any cash or other property from the owner that may be subject to forfeiture under current law. Thus, a seizure is when an officer of the law takes possession of an individual's property. This is typically the first step in the asset forfeiture process. For the police to seize an individual's property, most jurisdictions require that the officer merely have "probable cause" to believe the property is subject to forfeiture under existing law. Some jurisdictions, however, have additional requirements before real property can be seized. What happens after a seizure depends on the jurisdiction, the type of property seized, and the 
type of forfeiture that is being sought. The United States Department of Justice (2009) defines forfeiture as "the taking of property derived from a crime, involved in a crime, or that which makes a crime easier to commit or detect without compensating the owner" (p.8); although the degree of certainty required to demonstrate an association with criminal conduct varies and is a matter of some controversy ( Edgeworth, 2008 and Worrall, 2004).

Very generally, there are two types of asset forfeitures - civil and criminal. The vast majority of states and the federal government allow for both types of forfeitures. ${ }^{1}$ Criminal forfeitures are called in personam ("against a person") proceedings. In these proceedings, a forfeiture action occurs against a person after he/she has been convicted of an underlying criminal offense beyond a reasonable doubt. There is generally little criticism about criminal asset forfeiture because of the due process protections afforded individuals in such proceedings.

Civil forfeitures are called in rem proceedings, which translates from Latin as "against a thing" or "about a thing." A person's property is the target of the proceeding and the owner or other interested party is secondary. Furthermore, because civil liberties extend only to individuals, and not to property, owners of seized property have fewer protections than in legal actions against the individuals themselves (Blumenson \& Nilsen, 1998; Hadaway, 2000). Most criticisms of asset forfeiture are directed against activities conducted under civil forfeiture laws. There are several forms of civil forfeiture. What the government is required to demonstrate in civil forfeiture proceeding varies depending on statutory language. While some state statutes have strict rules on the type of forfeiture actions required, other states and the federal government give law enforcement and prosecutors considerable discretion in selecting how to proceed in forfeiture actions (see generally Edgeworth, 2008).

Once forfeited, cash can be distributed to law enforcement, prosecutors' offices, schools, drug education and rehabilitation programs, or to the general fund of the city, county, or state. Property, such as cars, cell phones, or homes, can be kept for official use by law enforcement or it can be sold and the proceeds can be used in the same manner prescribed for cash forfeitures (see Edgeworth, 2008 and Williams, 2002b).

\section{Federal equitable sharing}

One of the lesser known aspects of asset forfeiture is the practice known as "equitable sharing". The Comprehensive Crime Control Act of 1984 allows state and local law enforcement agencies to transfer assets and property they seize to federal law enforcement agencies. Federal law enforcement officials can take possession of this property and initiate federal forfeiture actions against the assets as long as the "conduct giving rise to the seizure is in violation of federal law and where federal law provides for forfeiture" (United States Department of Justice, 2009, p. 6). Seized assets transferred to the federal government through equitable sharing agreements may be forfeited regardless of whether an individual is charged, let alone convicted, of a crime in either state or federal court. If the assets are successfully forfeited to the federal government, the funds are deposited in the appropriate federal asset forfeiture fund. The Department of Justice Asset Forfeiture Fund (hereafter AFF) accepts funds from the majority of federal law enforcement agencies, including the FBI, DEA, and ATF. The Treasury Forfeiture Fund accepts deposits from Treasury agencies such as the Secret Service and financial and consumer agencies within the federal government. After the assets are forfeited and deposited into a federal forfeiture fund, state and local agencies receive a payment based on a percentage of the total value of the assets depending on the specific type and circumstances of that particular case (U.S. Dept. of Justice, 2009). 
There are two forms of equitable sharing activities (U.S. Dept. of Justice, 2009). Joint investigative forfeitures are the result of investigative activities involving the cooperation of federal and state or local law enforcement agencies. These are particularly common with drug and gang task forces involving federal, state, and local law enforcement agencies. The percentage of funds shared with state and local agencies is a function of their role and effort in a particular seizure. Adoptive forfeitures occur when state and local agencies seize assets as the result of their investigation of state crimes. If the original crime is also a federal crime, the property is forfeitable under federal law. State and local agencies may then transfer seized property to federal law enforcement agencies that can elect to "adopt" this property for federal forfeiture proceedings. State and local agencies receive eighty (80) percent of the assets obtained from adoptive forfeitures and the federal government retains the remaining twenty (20) percent to offset costs associated with federal fund operations (U.S. Department of Justice, 2009).

The rationale for joint forfeitures is that the federal government can serve as the sole processor of potentially complicated seizure and forfeiture activities (Edgeworth, 2008 and Williams, 2002a). Furthermore, for geographic areas that may involve a multi-state task force, the federal forfeiture laws can avoid conflicts between statutes affecting different state and local agencies, creating a more equitable return on agency participation. Adoptive forfeitures are more controversial and have been the subject of considerable scholarly criticism (Blumenson and Nilsen, 1998 and Worrall, 2004; Hadaway, 2000;Levy, 1996 and Duffy, 2001). Government officials (Cassella, 2007 and United States Department of Justice, 2008b) and proponents of adoptive forfeitures (Edgeworth, 2008) frequently cite improved inter-agency coordination and cooperation, more efficient forfeiture processing, and tougher federal criminal penalties for many crimes (especially drug crimes). Critics note that these are rather superficial rationales and argue that the most reasonable explanation is that it is in the financial interests of many state and local agencies to process forfeitures through the federal government rather than using their own existing state legal framework to do so (Blumenson \& Nilsen, 1998; Levy, 1996 and Worrall, 2004). In effect, adoptive forfeitures allow state and local law enforcement to circumvent their own state laws and utilize federal law for processing forfeitures.

There are several reasons that state and local agencies would elect to use equitable sharing. First, different states may require different standards of proof to forfeit property. Some of these are more restrictive than the federal government's preponderance of the evidence standard. When state and local agencies transfer seized property to the federal government for forfeiture, that property is subject to the federal government standard, even if the standard in the jurisdiction from which the property was originally seized was more restrictive (Duffy, 2001 and United States Department of Justice, 2009). Thus, in some states, adoptive forfeitures are more likely to be successful if processed by the federal government than if they were retained and processed under state law. In essence, in some states, it is easier for the federal government to prevail in forfeiture actions.

Second, while some state statutes require forfeiture funds to be used for non-law enforcement purposes, state and local agencies can enter into agreements with other agencies to coordinate and enhance forfeiture activities. The funds obtained through such multi-agency agreements may be distributed consistent with the terms of these agreements and are generally exempt from the statutory restrictions on the use of forfeiture funds. Furthermore, the federal government requires that any funds distributed through equitable sharing arrangements be used solely to fund continuing law enforcement activities, even for agencies in jurisdictions where law enforcement receives none of the proceeds from state forfeitures (United States Department of 
Justice, 2009). The federal government will discontinue equitable sharing agreements with an agency if it is discovered that funds are being used for non-law enforcement purposes - even if the state statute requires such use. In this manner, the federal government's asset forfeiture program helps state and local agencies avoid restrictions in state law that would increase the effort necessary to forfeit funds or diminish the incentives for law enforcement to engage in such activities in the first place (Blumenson and Nilsen, 1998 and Duffy, 2001; Hadaway, 2000).

Finally, in an effort to encourage the creation of independent task forces designed to target particular crimes such as drug sales and trafficking, equitable sharing payments may be used to pay the salary of officer positions created to replace officers assigned to task forces (United States Department of Justice, 2009;Blumenson \& Nilsen, 1998; Hadaway, 2000). As long as an officer is assigned in a full-time capacity to the task force, equitable sharing payments may be used to pay the salary of a replacement officer on a one-to-one basis. This can occur even in states with statutory language prohibiting the use of forfeiture funds to pay officer salaries.

While a number of factors weigh into particular forfeiture decisions, it is difficult to ignore the substantial difference in the return on investment for many law enforcement agencies to engage in equitable sharing activities compared with state forfeiture actions. Through equitable sharing, many law enforcement agencies are able to receive funds from assets that may not have been forfeited under state law, they may receive a larger percentage of the assets forfeited than state law allows, and they may be able to use those resources to fund activities and costs that would otherwise be prohibited (Blumenson \& Nilsen, 1998;Hadaway, 2000;Duffy, 2001). ${ }^{2}$ While Edgeworth (2008) claims that the United States Department of Justice (2008a) policy manual for asset forfeiture discourages adoptive forfeitures simply to avoid more burdensome state laws, the actual language in the policy manual seemingly encourages such actions. ${ }^{3}$

\section{Financial incentives and "policing for profit"}

Perhaps the most significant criticism of asset forfeiture has focused on the purported financial incentives for law enforcement agencies to "police for profit" (Benson et al., 1995 and Blumenson and Nilsen, 1998Hadaway, 2000;Skolnick, 2008, Worrall, 2001, Worrall, 2004 and Duffy, 2001). As previously noted, most states allow law enforcement to keep a significant percentage, if not all, of the forfeiture proceeds from seizure activities. This, coupled with federal equitable sharing, provides opportunities for self-generating substantial agency resources.

Advocates of forfeiture activities typically highlight the use of forfeiture funds to promote social goods, such as restitution to crime victims (Rider, 2007; Edgeworth, 2008), and downplay or criticize the use of forfeiture proceeds for internal revenue generation (e.g. Edgeworth, 2008 and Williams, 2002a). They further maintain that such funds can only be used for statutorily approved purposes. As noted previously, however, the typical range of activities and expenses that are allowed under state statutes and equitable sharing arrangements represents significant benefits to law enforcement agencies. ${ }^{4}$ Occasionally, law enforcement officials and forfeiture advocates are quite explicit about the financial impact of forfeiture and its role in enforcement activities. AssetRecoveryWatch.com, a forfeiture training and advocacy organization, recently cited a senior U.S. Department official who, speaking at a conference in July 2009, "urged prosecutors and law enforcement officials to seize and forfeit more ill-gotten gains" (AssetRecoveryWatch.com, 2009).

There have been very few empirical studies of asset forfeiture and our knowledge about the factors associated with forfeiture activity is based primarily on surveys of law enforcement 
(Vecchi and Sigler, 2001 and Worrall, 2001), examining changes in department budgets (Benson et al., 1995 and Worrall, 2001), participant observation (Miller \& Selva, 1994), and investigative journalism reports (Burnett, 2008a, Burnett, 2008b, Burnett, 2008c, Burnett, 2008d, Poor and Rose, 1991a, Poor and Rose, 1991b, Poor and Rose, 1991c and Poor and Rose, 1991d; see generally Keller \& Wright, 2004). The limited empirical research on the topic, however, suggests that forfeiture creates powerful financial incentives and revenue production does influence operational decisions in some law enforcement agencies. Worrall (2001) surveyed 770 police managers and executives and found that almost forty (40) percent of respondents agreed or strongly agreed to the statement that civil forfeiture is "necessary as a budget supplement" (emphasis added). Evidence of this is further provided by Miller and Selva (1994) who found that police supervisors were keenly aware of the financial benefit of engaging in forfeiture activities and frequently made operational decisions to maximize perceived financial rewards. They report observing, "many such cases in which the operational goal was profit rather than the incarceration of drug offenders. The pursuit of profit clearly influenced policies on case selection" (Miller \& Selva, 1994, p.325). Vecchi and Sigler (2001) claim that the direct payment of forfeiture funds by the federal government to federal, state, and local agencies represents "a virtual cash cow" for these agencies.

Financial incentives may be particularly powerful for state and local law enforcement agencies that have limited resources and are susceptible to dynamic budgetary environments (Benson et al., 1995, Burnett, 2008c and Vecchi and Sigler, 2001). Benson et al. (1995) found that police bureaucracies' aggressive enforcement of drug laws was associated with budgetary incentives for such activities (see also, Baicker \& Jacobson, 2007). Burnett, 2008a, Burnett, 2008b, Burnett, 2008c and Burnett, 2008d reported that some Texas sheriffs' departments rely on forfeited money for up to one-third of their budgets. While forfeiture activities certainly vary across jurisdictions, it appears that many law enforcement agencies consider asset forfeiture to be an essential source of continuing revenue (Burnett, 2008b; see also Benson et al., 1995 and Worrall, 2001). Vecchi and Sigler (2001) claim that, despite claims otherwise, "(W)hat is evident from their behavior is that federal, state, and local governments use assets forfeiture to generate revenue" (p.75).

Perhaps the clearest evidence of the importance of generating revenues through forfeiture is the political pressure the law enforcement lobby has exerted to prevent reforms to asset forfeiture laws at the state and federal level (Blumenson and Nilsen, 1998, Hyde, 1995, Levy, 1996 and Worrall, 2004). Blumenson and Nilsen (1998) documented how lobbying by law enforcement resulted in considerable revisions and modifications to forfeiture reform efforts. Perhaps most noteworthy were lobbying efforts against amendments to federal asset forfeiture laws that would have required equitable sharing payments be distributed in a manner consistent with the seizing agencies' own state forfeiture laws (Blumenson \& Nilsen, 1998). The amendments were repealed before they became effective. Similarly, pressure from law enforcement interest groups watered down important provisions of the bill that eventually became the federal Civil Asset Forfeiture Reform Act (2000; hereafter "CAFRA"; Worrall, 2004). In addition, the law enforcement lobby was able to add provisions that actually strengthened forfeiture powers in some circumstances (see Worrall, 2004 and Edgeworth, 2008).

Prior research suggests that revenue-generating incentives do influence law enforcement forfeiture activities. Furthermore, equitable sharing appears to be an important tool for many state and local law enforcement agencies that would be otherwise limited by state forfeiture laws. Dunn (n.d.) reported that, following passage of a Missouri state law requiring all forfeiture proceeds to be deposited in the state education fund, Missouri law enforcement agencies took 
specific steps to circumvent this law by increasing the use of equitable sharing activities rather than processing such cases under state forfeiture laws (see also von Kaenel, 1994). In one of the few empirical analyses of equitable sharing to date, Worrall and Kovandzic (2008) found that law enforcement agencies in jurisdictions where state law requires at least a portion of the proceeds from asset forfeitures to be used for law enforcement purposes had significantly higher levels of equitable sharing payments than agencies in jurisdictions where law enforcement could keep all such proceeds. The results indicated that law enforcement agencies in states that require law enforcement to share forfeiture proceeds are more likely to engage in equitable sharing in order to avoid state statutory restrictions. This is consistent with investigative reports (e.g. Burnett, 2008a, Burnett, 2008b, Burnett, 2008c and Burnett, 2008d) and scholarly research (Vecchi \& Sigler, 2001;Blumenson \& Nilsen, 1998) that highlight law enforcement efforts to maximize revenue production through equitable sharing.

The present study seeks to build upon the work of Worrall and Kovandzic (2008) by reexamining the extent to which law enforcement decisions to pursue forfeitures through federal equitable sharing agreements are influenced by different characteristics of their own state forfeiture laws. Critics of forfeiture contend that law enforcement operations are influenced by the perceived difficulty and rewards to engage in state forfeiture activities. If that is the case, equitable-sharing activities should be associated with state laws affecting the burden for the state to prevail in forfeiture activities and the percentage of the proceeds returned to law enforcement. If law enforcement agencies are circumventing their own laws in order to maximize revenue, this would provide additional evidence that police operations are influenced by a profit motive that has frequently been criticized by scholarly commentary (e.g. Skolnick, 2008;Worrall, 2004;Duffy, 2001 and Hadaway, 2000).

\section{Methods}

The present study uses a cross-sectional research design to assess the impact of three different characteristics of state asset forfeiture laws on federal payments received by state and local law enforcement agencies through the Department of Justice's Assets Forfeiture Fund. The study sample for the present study was restricted to municipal agencies and sheriffs' offices participating in the 2003 Law Enforcement and Administrative Statistics (LEMAS) survey (7th wave) with more than 100 full-time sworn officers and for which relevant data on two important potential confounding factors (e.g., drug arrest rate for manufacturing and selling of narcotic drugs and rate of violent crime) were not missing. ${ }^{5}$ The final sample size was 563 municipal police and sheriff's agencies. The decision to use agencies included in the LEMAS sample was based on the fact that it is nationally representative of all publicly funded state and local law enforcement agencies and includes information on many important potential confounding factors such as whether the agency is primarily responsible for drug enforcement in its locale and the number of full-time officers employed in a specialized drug unit or multi-agency drug task force. A more detailed discussion of the agency and community-level control variables included in the equitable sharing payment models is provided below.

\section{Explanatory variables - forfeiture laws}

Forfeiture laws differ from state to state and between states and the federal government. For purpose of the present study, the most relevant differences are those statutory requirements directly related to the financial incentive for law enforcement to engage in forfeiture activities (i.e. proceeds returned to law enforcement) and the procedural barriers to the government prevailing in forfeiture proceedings. In some states, forfeiture laws are more restrictive, meaning that it is more difficult for the government to prevail in forfeiture actions. In other states and the federal government, forfeiture laws are less restrictive, making it easier for the government to 
prevail and declare property forfeit. While some statutory variations are merely procedural and likely have minimal impact on forfeiture activities (see Edgeworth, 2008 for an exhaustive discussion of such differences), scholars and practitioners have identified several elements of forfeiture laws with important substantive and procedural implications (Blumenson \& Nilsen, 1998;Edgeworth, 2008, Sorens et al., 2008, Williams, 2002a and Worrall, 2004). Prior research indicates that two statutory elements, the burden in innocent owner claims and the standard of proof necessary for the state to demonstrate that property is subject to forfeiture, are particularly important burdens to the state (e.g. Edgeworth, 2008, Hyde, 1995, Sorens et al.,

2008 and Worrall, 2004). Combined, these laws represent significant incentives and barriers for law enforcement forfeiture activities and are used as the major predictors of forfeiture activity in the present study. ${ }^{6}$

\section{Forfeiture proceeds retained by law enforcement}

How the proceeds from forfeited assets are distributed, to whom, and restrictions on the use of those proceeds varies considerably across individual states as well as between states and the federal government. Some state statutes, for example, require that proceeds obtained through forfeiture activities be distributed for non-law enforcement purposes. In those jurisdictions where less than $100 \%$ of forfeiture proceeds are allocated to law enforcement, forfeiture assets may be used to fund drug treatment and education programs, special court programs, the general education fund of the jurisdiction, or even to the general fund of the budgeting agency or state. The percent of proceeds to law enforcement variable was coded based upon the minimum percentage of forfeiture proceeds to be returned to law enforcement according to state statute. ${ }^{7}$ This measurement strategy is superior to the "all-or-nothing" approach used by Worrall and Kovandzic (2008) who operationalized proceeds to law enforcement with a binary dummy variable coded 1 if state law provided 100 percent of proceeds be returned to law enforcement agencies and zero otherwise. Table 1 reveals the considerable variation across jurisdictions in the percentage of forfeiture proceeds that may be used for law enforcement. ${ }^{8}$

\section{Burden of proof in "innocent-owner" defense claims}

State forfeiture laws can also be distinguished by the degree of difficulty or the burden for the government to prevail in forfeiture actions. ${ }^{9}$ In the present analyses, the degree of difficulty is measured by two aspects of forfeiture laws. The first measure is which party (government or property owner) has the burden to establish or defeat "innocent owner" claims. The creation of an "innocent owner" defense was prompted by the media reports of questionable forfeiture activities and the United States Supreme Court decision in Bennis v. Michigan (1996). In Bennis, the plaintiff's car was used without her knowledge by her husband to secure the services of a prostitute. The husband was arrested and the car seized. Under Michigan law, vehicles used for such purposes were subject to seizure and forfeiture. Furthermore, existing Michigan law did not provide for a defense based on an owner's lack of knowledge about the use of the vehicle for illegal purposes. The wife appealed the forfeiture of the vehicle. The U.S. Supreme Court ruled against the plaintiff and held that property owners do not have a constitutional right to an innocent-owner defense in civil forfeiture actions. The critical public and political reaction to this ruling led to the inclusion of an innocent-owner defense in the CAFRA legislation that now applies to all federal forfeiture actions (see generally, Worrall, 2004) In 
Table 1

Percentage Proceeds to Law Enforcement ( ${ }^{*}$ indicates drug statutes)

\begin{tabular}{|c|c|c|c|c|c|c|c|c|c|c|}
\hline $100 \%$ & $95 \%$ & $90 \%$ & $85 \%$ & $80 \%$ & $75 \%$ & $65 \%$ & $63 \%$ & $60 \%$ & $50 \%$ & $0 \%$ \\
\hline $\begin{array}{l}\text { Alabama* } \\
\text { Alaska* } \\
\text { Arizona } \\
\text { Arkansas* } \\
\text { Delaware* } \\
\text { Georgia* } \\
\text { Hawaii } \\
\text { Idaho* } \\
\text { lowa } \\
\text { Kansas } \\
\text { Kentucky* } \\
\text { Massachusetts* } \\
\text { Michigan* } \\
\text { Montana* } \\
\text { Nevada } \\
\text { New Jersey } \\
\text { New Mexico } \\
\text { Oklahoma* } \\
\text { Pennsylvania* } \\
\text { South Dakota* } \\
\text { Tennessee* } \\
\text { Utah } \\
\text { Virginia* } \\
\text { Washington* } \\
\text { West Virginia* } \\
\text { Wyoming** }\end{array}$ & South Carolina* & $\begin{array}{l}\text { Illinois* } \\
\text { Minnesota } \\
\text { New Hampshire* } \\
\text { Rhode Island* } \\
\text { Texas* }\end{array}$ & Florida & $\begin{array}{l}\text { Louisiana* } \\
\text { Mississippi }^{*}\end{array}$ & Nebraska* & California* & Oregon & $\begin{array}{l}\text { Connecticut } \\
\text { New York }\end{array}$ & $\begin{array}{l}\text { Colorado } \\
\text { Wisconsin }\end{array}$ & $\begin{array}{l}\text { Indiana* } \\
\text { Maine } \\
\text { Maryland* } \\
\text { Missouri } \\
\text { North Carolina* } \\
\text { North Dakota* } \\
\text { Ohio } \\
\text { Vermont }\end{array}$ \\
\hline
\end{tabular}


Table 2

Burden of Proof for Innocent Owner Defenses (* indicates drug statutes)

\begin{tabular}{|c|c|c|}
\hline Owner & Government & Both \\
\hline Alaska* & California* & $\begin{array}{l}\text { Alabama* (government for real property; } \\
\text { owner for other property) }\end{array}$ \\
\hline Arizona & Colorado & $\begin{array}{l}\text { Indiana* (government for vehicles; } \\
\text { owner for other property) }\end{array}$ \\
\hline Arkansas* & Florida & $\begin{array}{l}\text { Kentucky* (government for real property; } \\
\text { owner for other property) }\end{array}$ \\
\hline Connecticut & Kansas & $\begin{array}{l}\text { Maine (government for real property; } \\
\text { owner for other property) }\end{array}$ \\
\hline Delaware* & Michigan* & $\begin{array}{l}\text { New Mexico (owner for conveyances; } \\
\text { government for other property) }\end{array}$ \\
\hline Georgia* & Oregon & $\begin{array}{l}\text { Utah (government has initial burden; } \\
\text { owner has opportunity to refute) }\end{array}$ \\
\hline \multicolumn{3}{|r|}{ (1) } \\
\hline \multicolumn{3}{|l|}{ Idaho* } \\
\hline \multicolumn{3}{|l|}{ Illinois } \\
\hline \multicolumn{3}{|l|}{ Iowa } \\
\hline \multicolumn{3}{|l|}{ Louisiana* } \\
\hline \multicolumn{3}{|l|}{ Maryland* } \\
\hline \multicolumn{3}{|l|}{ Massachusetts* } \\
\hline \multicolumn{3}{|l|}{ Minnesota } \\
\hline \multicolumn{3}{|l|}{ Missouri } \\
\hline \multicolumn{3}{|l|}{ Montana* } \\
\hline \multicolumn{3}{|l|}{ Nevada } \\
\hline \multicolumn{3}{|l|}{ New Hampshire* } \\
\hline \multicolumn{3}{|l|}{ New York } \\
\hline \multicolumn{3}{|l|}{ North Carolina* } \\
\hline \multicolumn{3}{|l|}{ North Dakota* } \\
\hline \multicolumn{3}{|l|}{ Oklahoma* } \\
\hline \multicolumn{3}{|l|}{ Pennsylvania* } \\
\hline \multicolumn{3}{|l|}{ Rhode Island* } \\
\hline \multicolumn{3}{|l|}{ South Carolina } \\
\hline \multicolumn{3}{|l|}{ South Dakota* } \\
\hline \multicolumn{3}{|l|}{ Tennessee* } \\
\hline \multicolumn{3}{|l|}{ Texas* } \\
\hline \multicolumn{3}{|l|}{ Vermont } \\
\hline \multicolumn{3}{|l|}{ Virginia* } \\
\hline \multicolumn{3}{|l|}{ Washington* } \\
\hline \multicolumn{3}{|l|}{ West Virginia* } \\
\hline \multicolumn{3}{|l|}{ Wisconsin } \\
\hline Wyoming* & & \\
\hline
\end{tabular}


addition, all remaining states that previously did not have an innocent-owner defense, including Michigan, eventually passed legislation barring the forfeiture of innocent-owner property. ${ }^{10}$ In most jurisdictions, an innocent-owner defense is considered an "affirmative defense". As a result, once the government has met its burden to demonstrate that the property is subject to forfeiture, the burden shifts to the purported owner to establish their "innocence", which would exempt the property from forfeiture. The innocent owner burden variable, therefore, represents which party has the burden (the state or the property owner) to establish whether the property owner qualifies as an innocent owner under state law. ${ }^{11}$ Table 2 summarizes which party has the burden of establishing whether an owner is statutorily "innocent" under various state laws.

\section{Standard of proof necessary to forfeit property ${ }^{12}$}

The second measure of statutory burden is the standard of proof required for the government to prevail in forfeiture proceedings. In American jurisprudence, different standards of proof are required for different types of legal issues or actions. Conceptually, these standards can be arranged on a continuum, rank ordering them from the least to the most difficult to establish. Reasonable suspicion is generally considered the lowest standard of proof. This is the standard required for the police to stop motorists suspected of moving violations and merely requires that an officer has reasonable grounds to believe that a moving violation occurred. Probable cause is an important concept in criminal justice because it represents the degree of certainty Probable cause is not easily defined and the courts have ruled that the "totality of the circumstances" should be considered in determining whether a particular conclusion was reasonable. It is the standard necessary in most jurisdictions to satisfy the seizure of property for forfeiture purposes. The preponderance of the evidence standard is commonly used in civil proceedings. An important distinction between preponderance and probable cause is that preponderance of the evidence implies a "more likely than not" character. Probable cause does not necessarily imply a greater degree of certainty, but rather an assessment of whether the party had good cause to engage in a particular action ( Tomkovicz, 1997; see also Illinois $v$. Gates, 1983). Thus, a preponderance standard is generally considered to be higher than mere probable cause ( Federal Bureau of Investigation, 2003). Importantly, the federal government utilizes the preponderance standard to determine whether property is subject to forfeiture. A clear and convincing standard is also used in some civil proceedings and is required for civil asset forfeiture in several states. It represents a higher degree of certainty than probable cause or preponderance, but is less than the beyond a reasonable doubt standard. Finally, beyond a reasonable doubt (occasionally phrased "reasonable certainty") is the highest standard of proof found in American law and is most commonly associated with the standard required to convict a defendant of criminal charges. The reasonable doubt standard does not require absolute certainty; however, it does require more than clear and convincing evidence. Very few states require a beyond a reasonable doubt standard for asset forfeiture. In a limited number of states, all asset forfeiture actions are considered criminal in personam actions and require that a defendant be convicted of a crime for which asset forfeiture is a possible consequence of conviction. In addition, several states require a criminal conviction for particular types of crimes (in particular, certain drug law violations) before an individual's assets may be forfeited. It is not surprising that law enforcement officials and proponents of asset forfeiture often criticize and challenge the few state laws with such a difficult standard for the government to prevail in forfeiture activities ( Blumenson and Nilsen, 1998, Hadaway, 2000 and Worrall, 2004).

For the present study, the standard of proof variable is a measure of the degree of certainty the government is required to meet to determine if property is subject to forfeiture. Some states require a different standard depending on the type of property. Most commonly, in states with two forfeiture standards, the higher one is for the forfeiture of real property such as land and homesteads and the lower standard is for seized cash and/or property under a specific dollar 
value. We considered these potentially meaningful distinctions and coded states with two standards as falling between the different standards. ${ }^{13}$ Table 3 identifies the standard of proof required under different state laws.

\section{Dependent variable}

Similar to Worrall and Kovandzic (2008), we rely on measures of equitable sharing to determine whether agencies in more restrictive jurisdictions receive more equitable sharing proceeds. Specifically, the dependent variable in the following analyses is the per capita amount of equitable sharing payments of cash and sale proceeds returned to state and local law enforcement agencies through the Department of Justice's Asset Forfeiture Program (AFP). ${ }^{14}$ The use of equitable sharing proceeds data is a meaningful test of whether equitable sharing is used to circumvent restrictive or less profitable state laws. Unlike Worrall and Kovandzic (2008) who used a single year measure of equitable sharing payments, we use a five-year average centered on the year 2002. Specifically, we average equitable-sharing payments received by agencies for fiscal years 2000 to $2004 .{ }^{15}$ The rationale for using a multi-year average is that it should provide a more reliable picture of an agency's reliance on equitable-sharing payments than estimates derived from a single-year which may be skewed by a few very large forfeitures. The average dollar amount by resident population is used to create a five-year average per equitable sharing payments of cash and sale proceeds returned to state and local law enforcement agencies through the Department of Justice's Asset Forfeiture Program (AFP). ${ }^{14}$ The use of equitable sharing proceeds data is a meaningful test of whether equitable sharing is used to circumvent restrictive or less profitable state laws. Unlike Worrall and Kovandzic (2008) who used a single year measure of equitable sharing payments, we use a five-year average centered on the year 2002. Specifically, we average equitable-sharing payments received by agencies for fiscal years 2000 to $2004 .{ }^{15}$ The rationale for using a multi-year average is that it should provide a more reliable picture of an agency's reliance on equitable-sharing payments than estimates derived from a single-year which may be skewed by a few very large forfeitures. The average dollar amount by resident population is used to create a five-year average per capita measure of equitable sharing payments. Equitable-sharing payments were obtained from audited reports overseen by the Office of the Inspector General. ${ }^{16}$

\section{Dependent variable}

Similar to Worrall and Kovandzic (2008), we rely on measures of equitable sharing to determine whether agencies in more restrictive jurisdictions receive more equitable sharing proceeds.

Specifically, the dependent variable in the following analyses is the per capita amount of equitable sharing payments of cash and sale proceeds returned to state and local law enforcement agencies through the Department of Justice's Asset Forfeiture Program (AFP). ${ }^{14}$ The use of equitable sharing proceeds data is a meaningful test of whether equitable sharing is used to circumvent restrictive or less profitable state laws. Unlike Worrall and Kovandzic (2008) who used a single year measure of equitable sharing payments, we use a five-year average centered on the year 2002. Specifically, we average equitable-sharing payments received by agencies for fiscal years 2000 to $2004 .{ }^{15}$ The rationale for using a multi-year average is that it should provide a more reliable picture of an agency's reliance on equitable-sharing payments than estimates derived from a single-year which may be skewed by a few very large forfeitures. The average dollar amount by resident population is used to create a five-year average per capita measure of equitable sharing payments. Equitable-sharing payments were obtained from audited reports overseen by the Office of the Inspector General. ${ }^{16}$ 
Table 3

Standard of Proof in State Forfeiture Laws ("indicates drug statutes)

\begin{tabular}{|c|c|c|c|c|c|c|}
\hline Probable Cause & $\begin{array}{l}\text { Probable Cause/Preponderance } \\
\text { of the Evidence }\end{array}$ & $\begin{array}{l}\text { Preponderance of } \\
\text { the Evidence }\end{array}$ & $\begin{array}{l}\text { Preponderance of } \\
\text { the Evidence/Clear } \\
\text { and Convincing }\end{array}$ & Clear and Convincing & $\begin{array}{l}\text { Clear and Convincing/ Beyond } \\
\text { a Reasonable Doubt }\end{array}$ & $\begin{array}{l}\text { Beyond a Reasonable } \\
\text { Doubt }\end{array}$ \\
\hline $\begin{array}{l}\text { Alabama* } \\
\text { Alaska* } \\
\text { Delaware* } \\
\text { Illinois* } \\
\text { Massachusetts* } \\
\text { Missouri } \\
\text { Montana* } \\
\text { Rhode Island* } \\
\text { South Carolina* } \\
\text { Wyoming* }\end{array}$ & $\begin{array}{l}\text { Georgia* } \\
\text { North Dakota* } \\
\text { South Dakota* } \\
\text { Washington* }\end{array}$ & $\begin{array}{l}\text { Arizona } \\
\text { Arkansas* } \\
\text { Hawaii } \\
\text { Idaho* } \\
\text { Indiana } \\
\text { lowa } \\
\text { Kansas } \\
\text { Louisiana* } \\
\text { Maine } \\
\text { Maryland } \\
\text { Michigan } \\
\text { Mississippi* } \\
\text { New Hampshire* } \\
\text { New Jersey } \\
\text { Oklahoma } \\
\text { Pennsylvania* } \\
\text { Tennessee* } \\
\text { Texas } \\
\text { Virginia* } \\
\text { West Virginia* }\end{array}$ & $\begin{array}{l}\text { Kentucky* } \\
\text { New York } \\
\text { Oregon*" }\end{array}$ & $\begin{array}{l}\text { Colorado } \\
\text { Connecticut } \\
\text { Florida } \\
\text { Minnesota } \\
\text { Nevada } \\
\text { New Mexico } \\
\text { Ohio* } \\
\text { Utah } \\
\text { Vermont* }\end{array}$ & California & $\begin{array}{l}\text { Nebraska* } \\
\text { North Carolina } \\
\text { Wisconsin* }\end{array}$ \\
\hline
\end{tabular}




\section{Control variables}

Our analyses include numerous agency and community-level control variables. We were particularly concerned to control for variables that may have potentially preceded in causal time order (or occurred approximately at the same time), or mediated the relationship between state asset forfeiture laws and the per capita dollar value of assets seized. Failing to control for the former type of variables (i.e. antecedent variables) would lead to spurious correlations for the state asset forfeiture law variables. On the other hand, controlling for the latter set of variables (i.e. intervening variables) serves to clarify the nature of the relationship between state laws governing asset forfeiture and asset forfeiture activity engaged in by law enforcement. Specifically, we controlled for the number of full-time officers assigned to special or multi-agency drug enforcement units to examine whether such units mediate the link between state asset forfeiture laws and forfeiture activity. One might hypothesize, for example, that law enforcement agencies in less restrictive asset forfeiture states may be more inclined to assign a larger number of full-time officers to specialized drug units because doing so is likely to lead to more drug-related asset forfeiture activity and eventually, additional revenue for the agency. Data on the number of full-time officers assigned to specialized or multi-agency drug units were obtained from the LEMAS dataset.

We also included the arrest rate (per 100,000 population) for drug manufacturing and selling and the violent crime rate (per 100,000 population) in the regression models because both variables may influence both the type of civil asset forfeiture statutes put in place by state policy makers and the amount of drug asset forfeiture activity a jurisdiction can reasonably be expected to engage in based on the sheer volume of drug-related transactions (i.e. more drug activity, more asset forfeiture). If this were true, failing to control for these potentially confounding variables would lead to spurious (or partly spurious) associations for the state asset forfeiture law variables. Data on the number of persons arrested for selling and manufacturing drugs was obtained from the Federal Bureau of Investigation's (FBI) Uniform Crime Reports (UCR). Similar to the dependent variables, we used a multi-year average (2001 to 2003) to solve the problem that drug activity fluctuates widely from year-to-year. Data on the number of violent crimes (i.e. homicide, forcible rape, robbery, aggravated assault) reported and recorded by law enforcement agencies for 2003 for each jurisdiction were also obtained from the FBI's UCR. Additional control variables included binary dummy variables denoting law enforcement agency type ( $1=$ municipal agency, $0=$ sheriff's department) and whether the agency was primarily responsible for enforcing drug laws in their respective jurisdiction ( $1=$ yes, $0=$ no). Data for both variables were obtained from the 2003 LEMAS dataset. The last set of control variables are fixed effects dummy variables for each of the nine U.S. Census regions. The census region dummies are used to control for any well-established and unobserved (or unmeasured characteristics) of the jurisdictions served by law enforcement agencies that vary at the regional level and that could be expected to influence both state asset forfeiture laws and drug-related asset forfeiture activity. Examples of such potential confounders would be regions of the U.S. where drug trafficking is more commonplace, and regions of the U.S. in close proximity to a major port of entry for drugs. Table 4 provides a brief description of each variable used in the analyses along with their means and standard deviations.

\section{Study hypotheses}

Investigative journalism reports (e.g., Poor \& Rose, 1991c) and prior studies on asset forfeiture (Levy, 1996;Hadaway, 2000;Vecchi and Sigler, 2001 and Worrall and Kovandzic, 2008Blumenson \& Nilsen, 1998;Duffy, 2001) have highlighted the importance of equitable sharing for state and local law enforcement. Specifically, these works contend that agencies in states with more restrictive and less profitable state laws engage in more equitable sharing activities to maximize their financial return on their forfeiture activities. Stated another way, 
Table 4

Variables in the Analysis

\begin{tabular}{|c|c|c|}
\hline Variable and Brief Description & Mean & SD \\
\hline \multicolumn{3}{|l|}{ Outcome Variables } \\
\hline $\begin{array}{l}\text { Per Capita Equitable Sharing Payments from Department } \\
\text { of Justice, 5-year average, Fiscal Years } 2000 \text { to } 2004\end{array}$ & 0.40 & 0.75 \\
\hline \multicolumn{3}{|l|}{ Asset Forfeiture Law Variables } \\
\hline Standard of Proof (Seven-point scale) & 3.74 & 1.73 \\
\hline Innocent Owner Burden (Three-point scale) & 1.55 & 0.86 \\
\hline Percent of Forfeiture Proceeds to Law Enforcement & 73.27 & 33.94 \\
\hline \multicolumn{3}{|l|}{ Departmental-Level Control Variables } \\
\hline $\begin{array}{l}\text { Law Enforcement Agency Responsible for Drug Enforcement, } \\
(1=\text { Yes })\end{array}$ & 0.97 & 0.16 \\
\hline Law Enforcement Agency Serves Municipality ( $1=$ Yes) & 0.69 & 0.46 \\
\hline $\begin{array}{l}\text { Full-time Law Enforcement Officers per 100,000 Population, } \\
\text { Special Drug Enforcement Unit }\end{array}$ & 5.68 & 6.36 \\
\hline $\begin{array}{l}\text { Full-time Law Enforcement Officers per 100,000 Population, } \\
\text { Multi-Agency Drug Task Force }\end{array}$ & 2.21 & 3.13 \\
\hline \multicolumn{3}{|l|}{ Community-Level Control Variables } \\
\hline $\begin{array}{l}\text { Drug Arrests for Manufacturing and Selling per 100,000 } \\
\text { Population, Average } 2001 \text { to } 2003\end{array}$ & 104.40 & 173.99 \\
\hline Violent Crime Rate per 100,000 Population & 487.38 & 464.03 \\
\hline
\end{tabular}

Notes: Descriptive statistics are for all cases with valid data on a given variable. Unless otherwise noted, each variable refers to the year 2003. The mean and standard deviation for the forfeiture law variables are based on their original values (i.e., not centered).

agencies in jurisdictions with more rewarding or less burdensome forfeiture provisions are predicted to use federal equitable sharing less. Strictly speaking, it is not necessary for these agencies to utilize federal forfeiture procedures to obtain a meaningful financial return on their forfeiture operations. Similarly, the chances of prevailing in a forfeiture proceeding may actually be greater for agencies located in states where the burden-of-proof is lower at the state level than at the federal level.

Perhaps more importantly, it is unlikely that the different provisions of state civil forfeiture laws act independently of one another. Rather, each provision is probably considered in conjunction with the other provisions by law enforcement executives in determining whether to process forfeiture activities through state law or federal equitable sharing. Therefore, we also examine the extent to which the main effects of each forfeiture provision on equitable sharing payments are modified by other provisions of the law. For example, agencies located in states that allow them to retain a sizable share of forfeiture proceeds will be even more disinclined to pursue

equitable sharing payments if the state's standard of proof threshold to forfeit assets is lower than required under federal law.

In the present study, we are able to test several recurring hypotheses about civil forfeiture that have, to date, been examined with rudimentary measures of state forfeiture laws or anecdotal evidence based on journalistic reports: 
Hypothesis 1. Law enforcement agencies located in states that allow them to receive larger percentages of forfeiture proceeds will receive lower equitable-sharing payments, ceteris paribus.

Hypothesis 2. Law enforcement agencies located in states with lower standard of proof thresholds to forfeit assets will receive lower equitable-sharing payments, ceteris paribus.

Hypothesis 3. Law enforcement agencies located in states in which the burden of proof in a state innocent owner defense is on the property owner will receive lower equitable-sharing payments, ceteris paribus.

Hypothesis 4. Law enforcement agencies able to receive larger percentages of forfeiture proceeds under state law will receive lower equitable-sharing payments if the standard of proof threshold to forfeit assets is lowered, ceteris paribus.

Hypothesis 5. Law enforcement agencies able to receive larger percentages of forfeiture proceeds will receive lower equitable-sharing payments if the burden of proof in a state innocent owner defense is on the property owner, ceteris paribus.

Hypothesis 6. Law enforcement agencies located in states with lower standards of proof thresholds will receive lower equitable-sharing payments if the burden of proof in a state innocent owner defense is on the property owner, ceteris paribus.

\section{Analytic procedures}

We used a censored regression model to determine the impact of three key components of state asset forfeiture laws on the per capita dollar value of equitable sharing payments received from the DOJ's AFF. Censored regression models take into account potential biases that may be present when some observations on the dependent variable are not observable, as is the case here. In the present study, the equitable sharing payment variable is concentrated at the lower limit value of zero as roughly eleven percent (63 out of 563) of the agencies in the study sample received no equitable sharing payments from the DOJ between fiscal years 2000 to 2004. The appropriate censored regression model in this case is the Tobit model (see Tobin, 1958). Tobit regression estimates a linear regression model for a left-censored dependent variable, where the dependent variable is censored from below.

If the probability of zero dollars related to equitable sharing payments were the only phenomenon to explain, probit regression would provide a suitable model. Of course, this would result in throwing away information on the value of equitable sharing payments received when it is available. That is the case here because if a law enforcement agency received an equitable sharing payment from DOJ, we know precisely how much they received. On the other hand, if there were no concentrations at a lower limit, and we only cared to explain the per capita dollar amount of equitable sharing payments received, OLS would be the appropriate regression estimator. But, since there is a piling up of values of the dependent variable at a limit (in this case \$0), OLS estimates are biased because the dependent variables are not continuous and unbounded. The solution to this problem is a hybrid of the two regression methods (probit and OLS) which economists refer to as Tobit models. Similar to standard OLS regression, the Tobit regression model assumes the error terms are normally distributed, independent between observations and uncorrelated with the independent variables. Model parameters are estimated via maximum likelihood. 
Although it is useful to examine ordinary Tobit coefficients for sign and significance, they are not readily interpretable as effect sizes like their ordinary least squares (OLS) counterparts (Wooldridge, 2005). The reason interpretation of Tobit coefficients are more problematic than traditional regression coefficients is because the former must account for two distinct types of observations on the dependent variable. The first set contains the observations for which the dollar value of equitable sharing payments received is zero. For these observations we know only the values of the independent variables and the fact that the dependent variable is less than or equal to zero. The second set consists of all observations for which the value of both the independent and dependent variables are known. Thus, two types of effects are modeled simultaneously in a Tobit regression model: (1) the effect on the per capita dollar value of equitable sharing payments received for cases with a nonzero value (uncensored) and (2) the effect on the probability of having a nonzero value for cases with the limit value of zero dollars (censored). ${ }^{17}$ A problem arises, however, because only a single coefficient is provided in the output of a Tobit analysis for each of the two state asset forfeiture law variables. Clearly, however, it is not possible for a single coefficient to capture both effects-one for cases at the lower limit value (zero dollars) and another for cases above the limit value (nonzero dollars). ${ }^{18}$

Fortunately, a decomposition procedure developed by McDonald and Moffitt (1980) can be used to disentangle Tobit coefficients in such a way that both different effects are quantified: (1) the effect of state asset forfeiture laws on the per capita dollar value of payments received from DOJ and (2) the effect of the laws on the probability of a law enforcement agency receiving a equitable sharing payment for those agencies failing to receive payments during the study period. Decomposing the Tobit coefficients provides for a more complete understanding of the two separate effects state asset forfeiture laws can have on equitable sharing payment activity. ${ }^{19}$ The Tobit regression models were estimated using the Tobit command in Stata Release 9.0.

\section{Results}

For purposes of interpretation, it is important to remember that the hypotheses under examination postulate different relationships. A negative relationship is predicted between the proceeds to law enforcement variable and equitable sharing, i.e. the greater the return on forfeiture actions under state law, the less likely agencies are to utilize federal equitable sharing. A positive relationship is hypothesized between the burden variables and equitable sharing receipts. The more burdensome the state law is on the government (i.e. higher standard or government burden in innocent owner defenses), the more likely law enforcement is to process their forfeiture actions through equitable sharing. It is also worth noting that all three law variables were centered around zero by subtracting the middling value of each variables scale from each agencies own value for that particular law variable. For example, the law variable measuring standard of proof value is centered such that an agency with a previous score of four is transformed to a score of zero while an agency with an original score of seven is transformed to a score of three. The rationale for centering the law variables in this manner was to facilitate the interpretation of subsequent Tobit regression models using two-way interaction terms between the three state law variables.

Table 5 presents results from a Tobit regression model relating per capita equitable-sharing payments received by law enforcement agencies to three important elements of state asset forfeiture laws: (1) the percent of forfeiture proceeds returned to law enforcement, (2) the "standard of proof" required by state law to determine whether property is subject to forfeiture, 
and (3) which party has the "burden of proof" in an innocent owner defense. Robust standard errors, which are clustered at the state level, are presented in brackets under the regression coefficients. Due to space limitations, coefficient estimates for the region fixed effects are not shown.

As seen in Table 5, the coefficients for all three state asset forfeiture variables are in the expected theoretical direction and statistically distinguishable from zero, although the coefficient for the percent of forfeiture proceeds variable is only significant at the more generous .10 level. Beginning with the share of forfeiture proceeds variable, the results indicate that law enforcement agencies residing in generous forfeiture states receive significantly lower equitable sharing payments. The finding that law enforcement agencies in less generous states process more forfeitures as equitable sharing forfeitures is consistent with the findings reported by Worrall and Kovandzic (2008) and provides initial support for Hypothesis 1. With respect to the legal hurdles faced by agencies in forfeiting assets, the positive coefficient on the state standard of proof variable provides empirical support for Hypothesis 2 and indicates that law enforcement agencies located in states with higher "standard of proof" thresholds receive greater amounts of equitable sharing proceeds. Thus, it appears that the "standard of proof" component of state forfeiture laws plays a significant and independent role in forfeiture decisions made by law enforcement. Lastly, the coefficient for the innocent owner variable indicates that placing the burden of proof in innocent owner defenses largely on the state is statistically associated with larger equitable sharing payments, a result that is consistent with Hypothesis 3 . Although these standard interpretations are informative, the decomposition procedure discussed above provides additional substantive information regarding the effects of the state asset forfeiture variables on per capita proceeds received through equitable sharing payments. For example, the coefficient in Column 2 for the share of proceeds variable indicates that among law enforcement agencies receiving equitable sharing payments between fiscal years 2000 to 2004 (Column 2), a 1 percent increase in the share of forfeiture proceeds that could be returned to the agency under state law is associated with a .0008-cent per capita reduction in equitablesharing payments. Using a more realistic percentage increase rate of 25 percent, this figure would jump to roughly 2 cents per capita. With regards to the probability of receiving an equitable-sharing payment among agencies with no payments (Column 3 ), the results imply a .0008 lower probability of receiving an equitable sharing payment for every 1 percent increase in the percentage of forfeiture proceeds that can be returned to the initiating agency. ${ }^{20}$ 
Table 5

Effect of State Asset Forfeiture Laws on Per Capita Equitable Sharing Payments, 5-Year Average, FY2000 to FY2004

\begin{tabular}{|c|c|c|c|}
\hline & $\begin{array}{l}\text { (1) } \\
\text { Coefficient [Cluster } \\
\text { Robust Standard Error] }\end{array}$ & $\begin{array}{l}\text { (2) } \\
\text { Effect of Change in State Asset Forfeiture } \\
\text { Laws on Average Per Capita Equitable } \\
\text { Sharing Payments, Among Those Receiving } \\
\text { Equitable Sharing Payments }\end{array}$ & $\begin{array}{l}\text { (3) } \\
\text { Effect of Change in State Asset } \\
\text { Forfeiture Laws on Probability } \\
\text { of Receiving Equitable Sharing } \\
\text { Payments }\end{array}$ \\
\hline \multicolumn{4}{|l|}{ State Asset Forfeiture Law Variables: } \\
\hline Percent of Asset Proceeds Returned to Law Enforcement Agency & $\begin{array}{l}-.0017^{*} \\
{[.0010]}\end{array}$ & $-.0008^{*}$ & $-.0008^{*}$ \\
\hline State Standard of Proof & $\begin{array}{l}.0379^{* *} \\
{[.0189]}\end{array}$ & $.0179^{* *}$ & $.0180^{* *}$ \\
\hline Innocent Owner Burden & $\begin{array}{l}.0905^{*+} \\
{[.0537]}\end{array}$ & $.0428^{* *}$ & $.0428^{* *}$ \\
\hline Law Enforcement Agency Responsible for Drug Enforcement, ( $1=$ Yes) & $\begin{aligned} .3191^{\circ} \\
{[.1744] }\end{aligned}$ & $.1348^{*}$ & $.1608^{*}$ \\
\hline Law Enforcement Agency Serves Municipality. ( 1 = Yes) & $\begin{array}{l}.1740^{* *} \\
{[.0885]}\end{array}$ & $.0802^{* *}$ & $.0838^{* *}$ \\
\hline $\begin{array}{l}\text { Full-time Law Enforcement Officers Per 100,000 Population, } \\
\text { Special Drug Enforcement Unit }\end{array}$ & $\begin{array}{c}.0020 \\
{[.0042]}\end{array}$ & .0009 & .0010 \\
\hline $\begin{array}{l}\text { Full-time Law Enforcement Officers Per 100,000 Population, } \\
\text { Multi-Agency Drug Task Force }\end{array}$ & $\begin{array}{l}.0168 \\
{[.0117]}\end{array}$ & .0079 & .0079 \\
\hline $\begin{array}{l}\text { Drug Arrests for Manufacturing and Selling per 100,000 Population, } \\
\text { 3-Year Average, } 2001 \text { to } 2003\end{array}$ & $\begin{array}{l}-.0003 \\
{[.0002]}\end{array}$ & -.0001 & -.0001 \\
\hline Violent Crime Rate per 100,000 Population & $\begin{array}{l}.0004^{* * *} \\
{[.0001]}\end{array}$ & $.0002^{* * *}$ & $.0002^{* * *}$ \\
\hline Standard Error of Estimate & 0.7619 & & \\
\hline Log-Likelihood Value & -623.34 & & \\
\hline Chi-squared & 290.14 & & \\
\hline Sample Size & 563 & & \\
\hline
\end{tabular}


Next, we explored the possibility of two-way interactions between the three state forfeiture law variables. We believe there is a strong theoretical basis to expect that the effects of any one characteristic of state asset forfeiture laws on equitable-sharing payments may be moderated by another aspect of the law. For example, agencies located in states where the standard of proof required by authorities to forfeit assets is greater (e.g., beyond a reasonable doubt) than the "preponderance of evidence" requirement at the federal level may be more inclined to turn forfeiture cases over to federal authorities even if state law permits agencies to keep a generous portion of the forfeited proceeds. Conversely, agencies located in more generous states with similar standard of proof requirements for seizing assets may be less inclined to turn cases over to federal authorities.

The results of the interaction analysis are reported in Table 6 . These interactions must be interpreted with care. Most importantly, the statistical significance of each law variable in isolation cannot be determined by simply looking at their t-ratios separately. In other words, the fact that the coefficient for the innocent owner variable is not significantly different from zero does not mean this characteristic of forfeiture restrictiveness does not have a significant impact on equitable sharing payments. Rather, the statistical significance of each law variable can only be determined when testing its importance in conjunction (referred to as a joint hypothesis test) with the interaction terms of which it is a part. Indeed, the $F$ statistic testing the joint hypothesis of each interactions involving the innocent owner variable are statistically significant.

The results clearly show that the interaction terms have a significant effect on per capita equitable sharing payments. Beginning with the two-way interaction between the share of forfeiture proceeds returned to law enforcement and the standard of proof variable, the results indicate agencies located in more generous forfeiture states will rely less heavily on federal forfeiture programs as the standard of proof for the government to prevail in state forfeiture actions is decreased. Specifically, per capita equitable-sharing proceeds for agencies located in states where the standard of proof required to forfeit assets is lowered from "preponderance/clear and convincing" to "prima facie/probable cause," i.e. from 0 to - 3) can be expected to decrease by 2 cents per person $\left[10^{*} .001+10^{*}-3^{*}(.0004)=-.002\right]$ for each 10 percent increase in the share of proceeds returned to law enforcement. This finding is consistent with Hypothesis 4.

Turning our attention to the results for the interaction term between the share of forfeiture proceeds and the innocent owner variable, results indicate that law enforcement agencies located in generous forfeiture states in which the burden of proof is on the state to show the property forfeited was ill-gotten, rely less heavily on equitable-sharing payments. For example, per capita equitable-sharing payments for agencies located in states where the burden in innocent owner defenses is on the government can be expected to increase by 3-cents per $\left[10^{*} .001+10 * 1 *(.002)=.03\right]$ for every 10 percent increase in state proceeds returned to law enforcement. On the other hand, a similar 10 percent increase can be expected to reduce per capita equitable sharing proceeds by 1 - cent per person $\left[10^{*} .001+10^{*}-1(.002)=0.01\right]$ when the burden of proof standard is on the claimant. Simply put, for agencies expecting large returns on forfeiture activity, placing the burden of proof on the owner to establish his or her innocence equates to less reliance on federal forfeiture programs. 
Table 6

Effect of State Asset Forfeiture Laws on Equitable Sharing Payments, Controlling for Potential Confounding Factors

\begin{tabular}{|c|c|c|c|}
\hline & $\begin{array}{l}\text { (1) } \\
\text { Coefficient [Cluster Robust } \\
\text { Standard Error] }\end{array}$ & $\begin{array}{l}\text { (2) } \\
\text { Effect of Change in State Asset Forfeiture } \\
\text { Laws on Average Per Capita Equitable } \\
\text { Sharing Payments, Among Those Receiving } \\
\text { Equitable Sharing Payments }\end{array}$ & $\begin{array}{l}\text { Effect of Change in State Asset } \\
\text { Forfeiture Laws on Probability } \\
\text { of Receiving Equitable Sharing } \\
\text { Payments }\end{array}$ \\
\hline \multicolumn{4}{|l|}{ Independent Variable } \\
\hline $\begin{array}{l}\text { Percent of Asset Proceeds Returned to Law Enforcement } \\
\text { Agency }\end{array}$ & $\begin{array}{l}.001^{* * *} \\
{[.001]}\end{array}$ & $.001^{* * *}$ & $.001^{* * *}$ \\
\hline Standard of Proof & $\begin{array}{l}.063^{* *} \\
{[.015]}\end{array}$ & $.030^{* *}$ & $.030^{* \approx}$ \\
\hline Innocent Owner Burden & $\begin{array}{l}-.056 \\
{[.059]}\end{array}$ & -.026 & -.026 \\
\hline $\begin{array}{l}\text { Percent of Asset Proceeds Returned to Law Enforcement } \\
\text { Agency x State Standard of Proof }\end{array}$ & $.0008^{* * *}$ & $.0004^{* * *}$ & $.0004^{* * *}$ \\
\hline Percent of Asset Proceeds Returned to Law Enforcement & $.004^{* * t}$ & $.002^{* * *}$ & $.002^{* * *}$ \\
\hline State Standard of Proof $x$ Innocent Owner Burden & $\begin{array}{l}.058^{* * *} \\
{[.013]}\end{array}$ & $.027^{* * *}$ & $.028^{* * *}$ \\
\hline $\begin{array}{l}\text { Law Enforcement Agency Responsible for Drug Enforcement, } \\
(1=\text { Yes })\end{array}$ & $\begin{array}{l}.340^{*} \\
{[.181]}\end{array}$ & $.142^{*}$ & $.172^{*}$ \\
\hline Law Enforcement Agency Serves Municipality, ( $1=$ Yes $)$ & $\begin{array}{l}.192 \\
{[.089]}\end{array}$ & .089 & .093 \\
\hline $\begin{array}{l}\text { Full-time Law Enforcement Officers Per 100,000 Population, } \\
\text { Special Drug Enforcement Unit }\end{array}$ & $\begin{array}{c}.002 \\
{[.004]}\end{array}$ & .001 & .001 \\
\hline $\begin{array}{l}\text { Full-time Law Enforcement Officers Per 100,000 Population, } \\
\text { Multi-Agency Drug Task Force }\end{array}$ & $\begin{array}{c}.018 \\
{[.012]}\end{array}$ & .009 & .009 \\
\hline $\begin{array}{l}\text { Drug Arrests for Manufacturing and Selling per } 100,000 \\
\text { Population, 3-Year Average, 2001 to } 2003\end{array}$ & $\begin{array}{l}-.0003 \\
{[.0002]}\end{array}$ & -.0002 & -.0002 \\
\hline Violent Crime Rate per 100,000 Population & $\begin{array}{c}.0004^{* * * *} \\
{[.0001]}\end{array}$ & $.0002^{* * *}$ & $.0002^{* * *}$ \\
\hline Standard Error of Estimate & 0.76 & & \\
\hline Log-Likelihood Value & -620.66 & & \\
\hline Chi-squared & 366.41 & & \\
\hline Sample Size & 563 & & \\
\hline
\end{tabular}

Notes: All state asset forfeiture law variables are centered at zero. Coefficient estimates for census region fixed effects are not shown. Robust standard errors clustered at the state level are reported. ${ }^{*}$ significant at .10 level; ${ }^{* *}$ significant at .05 level; ${ }^{* *}$ significant at .01 level. 
Lastly, the interaction term between the standard of proof and innocent owner law variables provides additional evidence that law enforcement agencies consider the restrictiveness of state forfeiture laws (in addition to the share of proceeds potentially returned) when making decisions on asset forfeiture activity. The coefficient on the interaction term indicates that the effects of the burden of proof threshold on per capita equitable-sharing payments differ significantly depending on whether the owner or government has the burden of proof in innocent owner defenses. Specifically, in states where the owners are presumed innocent (i.e. the burden is on the government to establish an owner's guilt), raising the standard of proof by one unit has the net effect of increasing per capita equitable-sharing payments by .057 cents per person[1*.030 $\left.+1^{*} 1^{*}(.027)=.057\right]$ as compared to only .003 cents per person $\left[1^{*} .030+1^{*}\right.$ $\left.1^{\star}(.027)=.003\right]$ when the burden switches from the government to the owner. Taken together, these results indicate that all three characteristics of state asset forfeiture laws operate both independently and in tandem with each other in explaining the amount of proceeds state and local law enforcement agencies can expect to receive through the Department of Justice's Assets Forfeiture Fund.

With respect to the control variables, the most notable finding is the significant negative association between the drug arrest rate and equitable-sharing payments. The most likely explanation is that agencies in high drug activity areas are also located in more generous forfeiture states. However, the results shown in Table 6 suggest this is not a very compelling explanation as the coefficient for the drug arrest rate was tiny and statistically insignificant. On the other hand, the coefficient for the violent crime rate variable indicates agencies embedded in high crime areas receive significantly greater equitable-sharing payments from DOJ. Lastly, the dummy variable for agency type shows that municipal agencies receive larger equitable-sharing payments than sheriff's offices.

\section{Conclusion}

The present study sought to investigate claims that police forfeiture behavior is affected by perceptions of the financial rewards for such activities. Using equitable sharing payments as the dependent variable of interest provides an opportunity to assess the relative importance of both financial incentive (i.e. equitable sharing forfeiture proceeds) and perceived effort (i.e. state standard of proof and innocent owner burden) in organizational decision-making regarding how to process forfeiture actions. It is worth noting that these are not merely theoretical speculations. As discussed earlier, there is substantial anecdotal evidence that law enforcement utilize a variety of tactics to generate the greatest revenue from their forfeiture operations. The present study merely examines prior commentary and observations with representative, national data.

Results from the present study demonstrate that all three factors of state forfeiture law that we studied - proceeds to law enforcement, innocent owner burden, and standard of proof - impact the extent to which state and local law enforcement agencies choose to pursue federal equitable sharing. Moreover, when state laws make forfeiture more difficult and less rewarding, agencies are even more apt to turn to the federal government's easier and more generous forfeiture procedures. This suggests that different aspects of forfeiture laws are associated with police activities in complex ways. While using a single measure to characterize a jurisdiction's forfeiture laws will likely be inadequate, the different measures of forfeiture laws used in our analyses were related to equitable sharing payments, both independently and in interaction with one another, in the hypothesized direction. Importantly, all of these findings held true - and indeed, became stronger - after controlling for relevant control variables such as drug arrests and violent crime rates. Put another way, the number of drug arrests or violent crimes in an area or the size or mission (drug-related or not) of a law enforcement agency does not "explain away" 
the effects of hurdles to forfeiture in state law. Even comparing similar agencies in similar crimerate areas, the agencies in states with more restrictive and less generous state laws will use equitable sharing more, presumably in an effort to avoid such laws. This also suggests, though indirectly, that states that make forfeiture more difficult and less rewarding see less forfeiture under state law (see Baicker \& Jacobson, 2007).

Like all social science research on organizational behavior, the present study suffers from several important limitations. Because it was not possible to estimate the total amount of forfeiture monies received by law enforcement agencies under their own civil forfeiture program for a large national sample of agencies, we were unable to directly examine whether agencies located in less restrictive forfeiture states pursue more vigorously civil asset forfeitures than in the more restrictive states. Instead, the present study examined the related question of whether agencies located in more restrictive forfeiture states are more likely to pursue civil forfeiture actions federally through the Department of Justice's Assets Forfeiture Program. Another limitation is that the dependent variable is based upon total proceeds and not the number of forfeiture actions processed. While the latter may be a better measure of forfeiture activity, that information does not exist for a large national sample of law enforcement agencies and, to our knowledge, is not available for even a single state. The five-year average for equitable sharing proceeds was used to minimize the impact of possible effects of outlier forfeiture activity, but this is certainly not a perfect solution. Finally, it is certain that our analyses overlooked important contextual factors that likely influence forfeiture activity by particular law enforcement agencies and perhaps within particular states (e.g. Baicker and Jacobson, 2007, Burnett, 2008a, Burnett, 2008b, Burnett, 2008c, Burnett, 2008d and Keller and Wright, 2004; Poor \& Rose, 1991;Vecchi and Sigler, 2001 and von Kaenel, 1994). The purpose of the study was not to explain forfeiture activity, but to use data for a very large and nationally representative sample of municipal law enforcement agencies to test critics' contentions that state forfeiture laws influence operational decisions by the police. We believe that this study is a meaningful effort towards answering such questions (Baumer, 2008).

It is likely that some will simply interpret the results of the present study as demonstrating the resourcefulness and creativity of law enforcement in securing organizational resources. In particular, the idea that complex organizations seek to maximize financial revenues and minimize the effort necessary to obtain resources is not surprising. However, the possibility of revenue-generating behavior by the police is not without its critics (e.g. Blumenson and Nilsen, 1998, Hyde, 1995, Levy, 1996 and Skolnick, 2008). A detailed examination of these criticisms is beyond the scope of this paper (but see Blumenson and Nilsen, 1998, Duffy, 2001, Hadaway, 2000 and Worrall, 2004). In general, however, the powerful incentives for profit-seeking found within forfeiture current laws is criticized as encouraging inappropriate enforcement activities and detracting from the proper role of law enforcement within a democratic state. The dependency of the police on public resources for their operations is an important check on police power. Self-generating revenues by the police through forfeiture potentially threatens the ability of popularly elected officials to constrain police activities. Perhaps such concerns partially explain the differences in state laws. If the legislators and the public wished for forfeiture to be very easy and rewarding to law enforcement, every state would have low standards of proof, limited innocent owner protections, and all proceeds would go exclusively to the police.

In sum, the present study found that law enforcement agencies in jurisdictions with more restrictive or less rewarding state forfeiture laws receive greater forfeiture proceeds through federal equitable sharing. These results provide compelling evidence that law enforcement agencies consider the legal burdens and financial rewards of their own state law compared to 
those under federal equitable sharing in determining how to process asset seizures. Whether such actions are viewed as appropriate, innovative, and utility-maximizing police behavior or something more problematic is a matter for the public and policy-makers to assess. Any discussion about these results, however, certainly raises political and normative questions about the independence of law enforcement from public oversight and the budgetary process as well as the appropriate role and limits of asset forfeiture by law enforcement.

\section{Acknowledgments:}

Partial funding for this study was provided by the Institute for Justice (IJ). IJ staff had no role in the methodological design of the present study, analysis of the data, authors' interpretation of the findings, or conclusions drawn from these findings.

The authors would like to thank Dick Carpenter and Scott Bullock from the Institute for Justice for their assistance and support during the completion of the study. In addition, the authors would like to thank Mark Schaffer for his helpful comments and Paul Ford, Michael Chase, and Steve DiGiantommaso for their assistance with data entry.

\section{Notes:}

1. Given the numerous variations across state and federal laws addressing forfeiture, much of the discussion about procedures and practice is rather general and it must be acknowledged that jurisdictional differences exist. We have chosen to only highlight those legal and procedural differences that have substantive relevance to actual practice and present analyses.

2. Even advocates of forfeiture activities acknowledge the circumvention of state forfeiture laws by law enforcement. For example, Edgeworth (2008) notes that while some states have homestead exemptions that preclude the forfeiture of real property that qualifies as a homestead, "a state homestead exemption is not a defense to a federal real property forfeiture case because the federal supremacy clause preempts the state exemption.... Therefore, in jurisdictions with state homestead exemptions, law enforcement will use the federal forfeiture system for any real property that may be exempted under state law" (p.248; see also Duffy, 2001 and von Kaenel, 1994).

3. According to the "Request for Adoption of State or Local Seizures" form (Appendix H), "As a general rule, if a state or local agency has seized property as part of ongoing state criminal investigation, and if the criminal defendants are being prosecuted in state court, the forfeiture action should also be pursued in state court. However certain circumstances may make federal forfeiture appropriate. These circumstances include, but are not limited to the following: (1) state laws or procedures are inadequate or forfeiture experience is lacking in the state system with the result that a state forfeiture action may be unfeasible or unsuccessful" (emphasis added; U.S. Department of Justice, 2008a, p. H-2).

4. Recently, the U.S. Department of Justice ruled that law enforcement agencies may use equitable sharing proceeds to help fund the creation of a National Law Enforcement Museum (Shanks \& Morison, 2008). To date, over \$10 million of the estimated \$80 million in construction costs have been donated by law enforcement agencies and the Department of Justice has ruled that future equitable sharing funds may be used to offset the operational costs of such a facility (Shanks \& Morison, 2008). 
5. The 2003 LEMAS sample was mailed to 3,154 agencies in December 2003. The sampling frame for the 2003 LEMAS survey was the 2000 Census of State and Local Law Enforcement Agencies (CSLLEA). Of the 3,154 agencies surveyed, 955 employed 100 or more sworn officer as of June 30, 2000. These 955 self-representing (SR) agencies included 574 local police departments, 332 sheriffs' offices, and 49 State law enforcement agencies. Self-reporting agencies in the LEMAS survey were defined as those agencies with 100 or more sworn full-time equivalent (FTE) employees and all State police agencies. The SR agencies were supplemented by a nationally representative stratified random sample of 2,199 nonselfrepresenting (NSR) agencies (1,539 local police departments and 660 sheriffs' offices) with less than 100 sworn personnel. The stratification variables used for the NSR agencies included the type of agency (local or sheriff), size of population served, and number of sworn personnel. The overall response rate for the 2003 LEMAS survey was 90.6 percent $(n=2,859$ agencies).

6. The method for distinguishing state asset forfeiture laws as reported in Table 1, Table 2 and Table 3 was based on the following research strategy. First, the authors reviewed the civil asset forfeiture statutes in each of the fifty states and coded each of these measures based on legal distinctions similar to those reported in Sorens, Muedini, and Ruger (2008). Next, the authors compared several existing sources (most notably Edgeworth, 2008, Sorens et al., 2008 and Worrall, 2004) for each measure for all states to minimize errors. Finally, each variable for each state was compared with the independent assessment by legal research staff at the Institute for Justice, a non-profit legal policy organization. This was done merely as an additional interrater reliability check. There were very few differences between our coding and that reported in other sources. The differences that did exist were typically the result of either errors by previous researchers or their focus on a different aspect of forfeiture laws. A very limited number of states have different statutory elements for drug-related cases. Scholarly and investigative journalistic reports on forfeiture overwhelmingly focus on forfeiture actions related to the war on drugs and in drug cases. Furthermore, the LEMAS measure on asset forfeiture specifically requests information pertaining to assets forfeited in association with enforcement of drug laws. Therefore, our decision was to code states based upon the laws regulating forfeiture in drug cases. These jurisdictions are noted within the appropriate table.

7. All state and the federal forfeiture statutes provide for the initial deduction of certain costs and expenses from the gross proceeds of forfeited assets. The required expenses to be covered vary, but may include property management costs, forfeiture processing expenses, reimbursement of third party interests, and victim restitution. Given that all jurisdictions require initial costs to be deducted from gross forfeiture revenues, the reported percentage of proceeds returned to law enforcement is perhaps best considered the percentage of net proceeds that are minimally allocated to law enforcement. The forfeiture distribution language within some statutes was imprecise in terms of the actual percentage guaranteed to law enforcement. In states with some vagueness, we coded the data based upon our reading of the statute and compared this coding with information reported in other sources (Edgeworth, 2008) and with independent assessments by the legal research staff at the Institute for Justice. We are confident that these procedures produced the most accurate assessment of proceeds to law enforcement. For any statutes with some remaining vagueness, however, our guiding principle was to code the percentages conservatively and in a manner that, if inaccurate, would bias results contrary to finding a significant relationship between the percentages and forfeiture revenue collected by agencies.

8. For this table, any percentage of funds required to be allocated to prosecutors and district attorneys were included as "law enforcement". Few states require a specific percentage of net proceeds to be allocated to prosecutors and, where present, are typically marginal (see 
Edgeworth, 2008, Table 10-1). Some states, however, require all forfeiture proceeds to be distributed by the district attorney associated with the seizing agency and other states' statutes are quite vague about the distinction between distributions to law enforcement and prosecutorial operations. Given the importance of cooperative relationships between police and prosecutors in forfeiture activities and the lack of distinction in many statutes, prosecution and district attorney allocations were included in law enforcement percentages. Examples of required allocations that were not counted as "law enforcement" include drug treatment programs, court expenses, and drug education programs (e.g. D.A.R.E. programs). The latter was identified in many statutes as an activity that "may" be funded with forfeiture proceeds, but very few required a specific percentage of net proceeds to be allocated to such programs. Statutory citations for Table 1, Table 2 and Table 3 are available upon request.

9. see generally, Edgeworth, 2008, Sorens et al., 2008 and Worrall and Kovandzic, 2008.

10. While the innocent owner defense in CAFRA is nearly universally agreed as progress, problems remain. The requirements and evidence necessary to establish an innocent owner defense vary across jurisdictions and may be difficult for innocent owners to demonstrate. In addition, the standard of proof necessary for an owner to establish innocence varies across jurisdictions. In most jurisdictions, the standard of proof is preponderance of the evidence; however, some states require innocent owners to demonstrate by clear and convincing evidence that their property should not be subject to forfeiture (Edgeworth, 2008).

11. This was coded as follows (lower numbers reflect less burden on the state): $1=$ the burden to establish innocence rests exclusively with the property owner/claimant; $2=$ the burden varies depending on the type of property being forfeited and $3=$ the burden rests exclusively with the government to establish that the claimant is not innocent. The coding strategy for the burden variables was similar to that utilized by Sorens et al., 2008.

12. Two important legal concepts are the "burden of proof" and "standard of proof". Although the terms are occasionally used interchangeably, for the purposes of this study, it is important to keep them distinct. Burden and standard of proof issues are some of the most controversial aspects of civil asset forfeiture. Most generally, the burden of proof indicates which party is required to establish its case. In asset forfeiture actions, the government has the burden of establishing that the property in question is subject to forfeiture. However, under federal law and many state laws, a property owner has the burden to establish that they are an innocent owner and that their property should be exempt from forfeiture (see Table 2). The standard of proof represents the degree of certainty the burdened party must meet to successfully prevail in a legal dispute.

13. The standard of proof variable was coded as follows (lower numbers reflect less burden on the state): 1 = prima facie/probable cause; 2 = probable cause and preponderance of the evidence; 3 = preponderance of the evidence; $4=$ preponderance and clear and convincing; $5=$ clear and convincing; 6 = clear and convincing and beyond a reasonable doubt and $7=$ beyond a reasonable doubt.

14. The most desirable test of the relationship between different state asset forfeiture laws and forfeiture activity would be to utilize data on reported forfeited assets by law enforcement against measures of different state forfeiture laws in those jurisdictions. While researchers have used LEMAS survey forfeiture variable to test this relationship (e.g. Worrall \& Kovandzic, 2008), upon further investigation, it appears that the LEMAS forfeiture measure has reliability problems for this purpose. The question in the LEMAS survey asks agencies to report the total amount of 
forfeiture proceeds received the previous calendar year as the result of participation in a drug asset forfeiture program. Thus, LEMAS forfeiture totals are based exclusively on forfeitures associated with drug-related offenses. Furthermore, the LEMAS survey does not ask agencies to distinguish proceeds obtained via equitable sharing activities compared with state laws (resulting in potentially serious measurement error for the forfeiture law variables). Finally, the number reported is based upon funds received by (and not forfeited by) law enforcement through forfeiture proceedings and excludes assets forfeited and distributed for non-law enforcement purposes. As a result, agencies in those states requiring the distribution of forfeiture proceeds for non-law enforcement purposes will only report the amount of assets they were able to keep under state law and/or the amount returned to the agency through equitable sharing. Thus, the LEMAS forfeiture variable actually measures only the amount of assets returned to an agency as a result of forfeitures associated with drug-enforcement activities and not the actual total assets forfeited as a result of that agency's actions. It may be possible to create estimates of non-reported forfeitures in jurisdictions receiving at least some percentage of forfeiture proceeds by applying weights to the dollars received by the percentage of forfeiture proceeds that are returned to that agency under law. The real measurement problem is for agencies in jurisdictions that are unable to retain any proceeds. In such jurisdictions, there will be an unknown amount of forfeiture activity that is not reported in the LEMAS survey measure; making it impossible to calculate reliable estimates of forfeiture activity for those agencies. To our knowledge, it is impossible to determine the actual total assets forfeited by state and local agencies with LEMAS or any other nationally representative data source.

15. Since the outcome variable was based on multi-year averages, it was necessary to review all state statutes to determine any if statutory changes occurred to the primary variables of interest during this time. A few states did change their forfeiture laws and these changes were coded into the dataset where appropriate to reflect the changes in law affecting law enforcement agencies in those states.

16. These are available at the Asset Forfeiture Program's website: www.usdoj.gov/jmd/afp/02fundreport/index.htm.

17. In our case the latent dependent variable is the propensity of law enforcement agencies to engage in asset forfeiture activity, but this dollar value is only realized if that capacity exceeds zero dollars. So, although many law enforcement agencies may have reported zero dollars related to drug asset forfeiture activity on the realized variable, they can be considered as having differing scores on the latent variable.

18. The Tobit coefficient represents the effect of an independent variable on the latent (unobserved) dependent variable. Because the latent dependent variable is not observed (otherwise we wouldn't need to use a censored regression model), it is rarely interpreted by researchers.

19. One potential pitfall with using local law enforcement data in a study examining the effects of state laws is that the law variables do not vary across jurisdictions within a particular state. As a result, errors in predicting asset forfeiture are likely to be correlated within clusters (i.e. states) and conventional estimates of standard errors for the state asset forfeiture law variables may be understated due to violations of the independence assumption (Moulton, 1990). To address this problem, we used cluster-adjusted standard errors that adjust for the fact that observations within states may not be independent (Williams, 2000). 
20. It is important to remember that while effects appear marginal, they are per capita. Based upon the results from Table 5, a law enforcement agency serving an average sized population $(300,000)$ that receives zero proceeds from state forfeiture actions would be expected to receive, on average, $\$ 24,000$ more in equitable sharing payments as compared to an agency that receives $100 \%$ of state forfeiture proceeds. Additionally, switching the burden of proof in innocent owner defense from the property owner to the government increased expected equitable sharing payments by $\$ 25,680$ for an average sized agency, Given that many law enforcement agencies serve populations much larger than 300,000 , results indicate that different features of forfeitures laws are associated with considerable differences in equitable sharing payments.

\section{References:}

AssetRecoveryWatch.com (2009). Justice Department targets assets in all cases with "forfeiture potential". Retrieved from organization website at. http:// assetforfeiturewatch.com

Baicker, K., \& Jacobson, M. (2007). Finders keepers: Forfeiture laws, policing incentives, and local budgets. Journal of Public Economics, 91, 2113-2136.

Baumer, E. (2008). Evaluating the balance sheet of asset forfeiture laws: Toward evidence-based policy assessments. Criminology and Public Policy, 7, 245-256.

Benson, B., Rasmussen, D., \& Sollars, D. (1995). Police bureaucracies, their incentives, and the war on drugs. Public Choice, 83, 21-45.

Blumenson, E., \& Nilsen, E. (1998). Policing for profit: The drug war's hidden economic agenda. University of Chicago Law Review, 65, 35-114.

Burnett, J. (2008a). Seized drug assets pad police budgets. National Public Radio: Dirty money: Asset seizures and forfeitures Retrieved April 14, 2009 from www.npr.org/ templates/story/story. php?storyld=91490480

Burnett, J. (2008b). Cash seizures by police prompt court fights. National Public Radio: Dirty money: Asset seizures and forfeitures Retrieved April 14, 2009 from www. npr.org/templates/story/story.php?storyld=91555835

Burnett, J. (2008c). Deputy has Midas touch in asset seizures. National Public Radio: Dirty money: Asset seizures and forfeitures Retrieved April 14, 2009 from www. npr.org/templates/story/story.php?storyld=91582619

Burnett, J. (2008d). Sheriff under scrutiny over drug money spending. National Public Radio: Dirty money: Asset seizures and forfeitures Retrieved April 14, 2009 from www.npr.org/templates/story/story.php?storyld=91638378

Cassella, S. (2007). Overview of asset forfeiture law in the United States. United States Attorneys' Bulletin, 55, 8-21. 
Civil Asset Forfeiture Reform Act, Pub. L. No. 106-185, 114 Stat. 202 (2000). Duffy, M. (2001). Note: A drug war funded with drug money: The federal civil forfeiture statute and federalism. Suffolk University Law Review, 34, 511-540.

Dunn, K. (n.d.). Reining in forfeiture: Common sense reform in the war on drugs. Retrieved August 12, 2009 from www.pbs.org/wgbh/pages/frontline/shows/drugs/ special/forfeiture.html

Edgeworth, D. (2008). Asset forfeiture: Practice and procedure in state and federal courts. Chicago: American Bar Association.

Federal Bureau of Investigation (2003, February 26). Probable cause. Congressional Record - Senate, Vol. 149. No. 31, p. S2749. Retrieved Government Printing Office website. http://www.gpoaccess.gov/crecord/03crpgs.html

Hadaway, B. (2000). Executive privateers: A discussion on why the Civil Asset Forfeiture Reform Act will not significantly reform the practice of forfeiture. University of Miami Law Review, 55, 81-121.

Hyde, H. (1995). Forfeiting your property rights. Washington, D.C.: The Cato Institute. Illinois v. Gates (1983) 462 U.S. 213.

Keller, T., \& Wright, J. (2004). Policing and prosecuting for profit: Arizona's civil asset forfeiture laws violate basic due process protections: Policy Report No. 198. Available from Goldwater Institute at. http://goldwaterinstitute.org/article/1294

Levy, L. (1996). License to steal: The forfeiture of property. Durham, NC: Carolina Academic Press.

McDonald, J. F., \& Moffitt, R. A. (1980). The uses of tobit analysis. The Review of Economics and Statistics, 62, 318-321.

Miller, M., \& Selva, L. (1994). Drug enforcement's double-edged sword: An assessment of asset forfeiture programs. Justice Quarterly, 11, 313-335.

Moulton, B. R. (1990). An illustration of a pitfall in estimating the effects of aggregate variables in micro units. Review of Economics and Statistics, 72, 334-338.

Poor, T., \& Rose, L. (1991a, May 5). Officer seizes sports car, ends up as its new owner. St. Louis Post Dispatch, p. 1A.

Poor, T., \& Rose, L. (1991b, December 15). Paralyzed student may lose his car for possessing $\$ 40$ worth of drugs. St. Louis Post Dispatch, p. 1A.

Poor, T., \& Rose, L. (1991c, December 17). Forfeiture "adoption" policy may rob citizen of due process. St. Louis Post Dispatch, p. 7A.

Poor, T., \& Rose, L. (1991d, December 29). Forfeiture scrutiny brings change. St. Louis Post Dispatch, p. 1A. 
Rider, N. (2007). Returning forfeited assets to victims. United States Attorneys Bulletin, 55, 30-55.

Shanks, J., \& Morison, K. (2008, Fall). Sheriffs can use federal asset forfeiture funds to support National Law Enforcement Museum. Sheriff (pp. 72-73). Available from http://www.sheriffs.org/file.asp?F=8D99B6C9D1CE46B8B9ED0185D5D47579. pdf\&N=SH08_6_Shanks_Morison.pdf\&C=spotlights/documents

Skolnick, J. (2008). Policing should not be for profit. Criminology and Public Policy, 7, 257-262.

Sorens, J., Muedini, F., \& Ruger, W. (2008). State and local public policies in 2006: A new database. State Politics and Policy Quarterly, 8, 309-326.

Tobin, J. (1958). Estimation of relationships for limited dependent variables. Econometrica, 26, 24-36.

Tomkovicz, J. J. (1997). Criminal procedure. New York: Aspen Publishers. United States Department of Justice (2008a). Manual: Asset forfeiture policy manual. Washington, DC: United States Department of Justice. Available from http://www. usdoj.gov/criminal/foia/docs/PolicyManual08.pdf

United States Department of Justice (2008b). Asset Forfeiture Fund and Seized Asset Deposit Fund Annual Financial Statement: Fiscal Year 2007. Washington, DC: United States Department of Justice. http://www.usdoj.gov/jmd/afp/01programaudit/ index.htm

United States Department of Justice (2009). Guide to equitable sharing for state and local law enforcement agencies. Washington, DC: United States Department of Justice Available from http://www.usdoj.gov/criminal/afmls/publications/guidetoeq09. pdf.

Vecchi, G., \& Sigler, R. (2001). Assets forfeiture: A study of policy and its practice. Durham, NC: Carolina Academic Press.

von Kaenel, F. (1994). Recent development: Missouri ups the ante in the drug forfeiture 'race to the res.' Washington University Law Quarterly, 72, 1469-1486.

Williams, R. (2000). A note on robust variance estimation for cluster-correlated data. Biometrics, 56, 645-646.

Williams, H. (2002a). Asset forfeiture: A law enforcement perspective. Springfield, IL: Charles C. Thomas Publishers.

Williams, M. (2002b). Civil asset forfeiture: Where does the money go? Criminal Justice Review, 27, 321-329.

Wooldridge, J. (2005). Introductory econometrics: A modern approach, 3rd edition. Florence, KY: South-estern College Publishing.

Worrall, J. (2001). Addicted to the drug war: The role of civil asset forfeiture as a 
budgetary necessity in contemporary law enforcement. Journal of Criminal Justice, 29, 171-187.

Worrall, J. (2004). The Civil Asset Forfeiture Reform Act of 2000: A sheep in wolf's clothing? Policing: An International Journal of Police Strategies and Management, 27, 220-240.

Worrall, J., \& Kovandzic, T. (2008). Is policing for profit? Answers from asset forfeiture. Criminology and Public Policy, 7, 219-244. 